\title{
Business Empowerment Program and Household Economic Welfare: Lesson from Indonesia*
}

\author{
Pudji PURWANTI $^{1}$, Edi SUSILO $^{2}$, Erlinda INDRAYANI ${ }^{3}$
}

Received: October 08, 2019 Revised: November 01, 2019 Accepted: November 15, 2019

\begin{abstract}
This study aims to analyze the household economic behavior of salt farmers participants in Salt Business Empowerment Program (Pugar) including of salt production, work flow, household revenue, the behavior of consumption of food and non-food items and the welfare level. This research followed a survey method by engaging 32 household farmers as participants. The findings revealed that the empowerment program was carried out through the technical assistance of salting production and the assistance of equipment and technology from Thread of Screw Filter and geoisolators to improve the quality of salt. The problems come when the marketing of salt is still limited to the collectors of salt which led to the price of salt level, manufacturers have not remained stable. Household revenue sources for some salt farmers also come from non-salt pond business activities. Farmer household revenue can be used to meet staple food consumption and non-food staple consumption. Based on the indicators of family welfare, households participating in the empowerment program were group into the category of prosperous families. In order to stabilize the price of salt at the producer level, government intervention in the people's salt trading system is needed.
\end{abstract}

Keywords : Empowerment Program, Salt Business, Household Welfare, Economic Activity, Indonesia

JEL Classification Code : D10, L21, I31

\section{Introduction}

Before 2011, Indonesia imported salt due to the domestic production was inefficient. The under average of national salt productivity at that time was not comparable to the level of salt demand and consumption in Indonesia. In 2009, the national salt production reached $1,265,600$ tons, still far

* We are grateful to anonymous referees and editor of the journal for their valuable comments and suggestions an attempt to improve the quality of the article.

1 First Author and Corresponding Author, Department of Fishery Agribusiness, Faculty of Fishery and Marine Science, Brawijaya University, Indonesia. [Postal Address: Jalan Veteran, Malang, East Java, 65145, Indonesia] Email: pudjipurwanti@gmail.com

2 Department of Fishery Agribusiness, Faculty of Fishery and Marine Science, Brawijaya University, Indonesia.

Email: olisuside@gmail.com

3 Department of Fishery Agribusiness, Faculty of Fishery and Marine Science, Brawijaya University, Indonesia. Email: pudjipurwanti@gmail.com

(c) Copyright: Korean Distribution Science Association (KODISA)

This is an Open Access article distributed under the terms of the Creative Commons Attribution Non-Commercial License (http://Creativecommons.org/licenses/by-nc/4.0/) which permits unrestricted noncommercial use, distribution, and reproduction in any medium, provided the original work is properly cited. lower than the national salt demand which about 2,865,600 tons per year (Trikobery et al., 2017). As a result, Indonesia imported salt from abroad, which amounts to 55 percent of the national salt needs. The level of salting land productivity in Indonesia at that time only averaged 60-70 tons per hectare for a year, which was quite low compared to Australia or India. In order to achieve salt self-sufficiency, in 2011, the Community of Salt Business Empowerment Program (Pugar) was introduced. The main objective of the program provides the salt business can grow and develop, that make the salt needs of the community can be met and reduce dependence on imported salt.

Community empowerment can be interpreted as effort to influence an activity to community. Constantino et al. (2012) stated that empowerment has been done appropriately to the community improved the capacity of government organizations and institutions that support development implementation. Community empowerment is primarily conducted in developing countries and shows effective results. Socio-economic empowerment has a significant impact on rural household poverty in Pakistan (Khan \& Haq 2015). Therefore, socio-economic empowerment needs to 
get attention for policy makers. Biswas et al. (2001) conducted study on empowering several households in Bangladesh through renewable energy technology. The results of empowerment create revenue for less farm households both from men and women and reduce environmental problems such as deforestation and indoor air pollution due to cooking with fuel that is not environmentally friendly. While Jagger (2008) suggested that empowerment in the management of open timber in northern Ethiopia household revenue-generating opportunities, but still pay attention to the environmental sustainability.

Meanwhile, some empowerment activities are carried out through the role of women. Acharya et al. (2005) examined the rural household empowerment program in Nepal. The findings of the empowerment program have greatly helped illiterate rural women to start effective small-scale economic activities, and absorb the female workforce. While the findings of Garikipati (2008) empowering women through lending are used to increase household productive assets to improve household revenue. Weber and Ahmad (2014) stated that there is a relationship between the women's loan cycle and the level of empowerment. A higher level of empowerment resulted from greater loan cycle.

Community participation in the preparation of program activities will determine the success of the program. A participatory approach by involving the target community of a program is one way that program objectives can be achieved (Chambers, 1996; Sulistiyani, 2007). Salt business empowerment in Pasuruan of Indonesia applied a participatory approach through the establishment of the Salt Farming Business Group (Kugar). The formation of salt farming business group is quite effective in strengthening the bond between salt farmers and facilitating the distribution of ingredients and the use of tools fairly and spread evenly (Prastio, 2019).

For these matters, the research intended to understand the implementation of business empowerment, conduct a salt pond production and behaviors households earning beside the salt ponds. Furthermore, this research aimed to analysis the households' revenue, household expenditure, and the welfare level of participant families.

\section{Methodology}

This research applied a survey method during July and September 2018 in Pasuruan of East Java, Indonesia. For the data collection, this study followed a rapid rural appraisal, besides being obtained through selected respondents it also relies on local information and is supported by the approach and interview of key figures. The total population is about 32 households consisting of 20 households from Panggungrejo, two households from Gadingrejo and 10 households from Bugul Kidul. Meanwhile, the sample of the study were gathered purposively from six groups of salt farmes in three districts namely Surya Jaya, Surya Sejahtera,
Crystal Laut, Sumber Salt, Setia Kawan and Samudra groups.

In addition, the data of this study includes (1) Implementation of pugar program (2) Production data of salt farmer respondents (3) Household productive behavior outside salt farms (4) Salt farmer household revenue (5) Household expenditure (6) Identification of household welfare level indicators based on indicators of family welfare The Central Bureau of Statistics in Indonesia. Furthermore, the data analysis to determine household revenue, calculate the financial analysis of salt ponds, outside of salt ponds and other businesses.

$$
\mathrm{RRTT}=\mathrm{RRTG}+\mathrm{RRTI}+\mathrm{RRTL}
$$

RRTT $=$ Total revenue of salt farmer households, RRTG $=$ revenue from salt ponds, RRTI $=$ revenue from milkfish farming, RRTL = other household revenue (trade, employees and wives of farmers).

Household expenditure is calculated based on food expenditure and non-food expenditure namely education, health and transportation costs as well as electricity and other non-food costs. The analysis of household welfare level of farmers is measured by using several indicators by considering the number of family member, health and nutrition, education, income, consumption level, housing, and social activities. In more detail, it is provided in the Table 1.

\section{Results and Discussion}

\subsection{The Implementation of the Fitter Program in Pasuruan}

The beginning of empowerment program in Pasuruan started since 2012. Meanwhile, the empowerment of pugar intensely carried out in 2015. The targets of the program in three sub-districts of Pasuruan are Panggungrejo, Gadingrejo and Bugul Kidul. Panggungrejo are appointed as the Center for program in Pasuruan of Indonesia, because they have the most extensive salt ponds. The location of pugar is used as a center of plan's production, mentoring and counseling, such as the evaluation of the program partcipants performance. In the implementation of pugar, formed six business unit of salt pond (Kugar).

The purpose of establishing business group is to facilitate coordination between the Fisheries and Maritime Services Office in charge of the pugar program and salt pond farmers participating in the program. The kugar organization consists of Trustees, Chair persons, Secretaries and Members. The pugar assistance program is called community direct assistance. Types of production equipment which submitted to salt farmers, such as Geoisolator, Slender, Water Pump, windmills, Salt rake, and barrow for transporting crops. Geoisolator is a media used for salt production, in the form of plastic sheeting which serves to 
accelerate the manufacture of salt and improve the quality of salt production. In addition to equipment assistance, the Government through the Department of Fisheries and Maritime Affairs also provides capital assistance to the business group of IDR 10,000,000 per group. Assistance from the government is quite effective in increasing salt pond production in Pasuruan. These results are consistent with the findings of Prastio (2019) which mentioned that salt business empowerment in Karawang is already well under control through the formation of groups, consistent training and provision of technological assistance by the government.

Table 1: Prosperous Family Indicator Rating

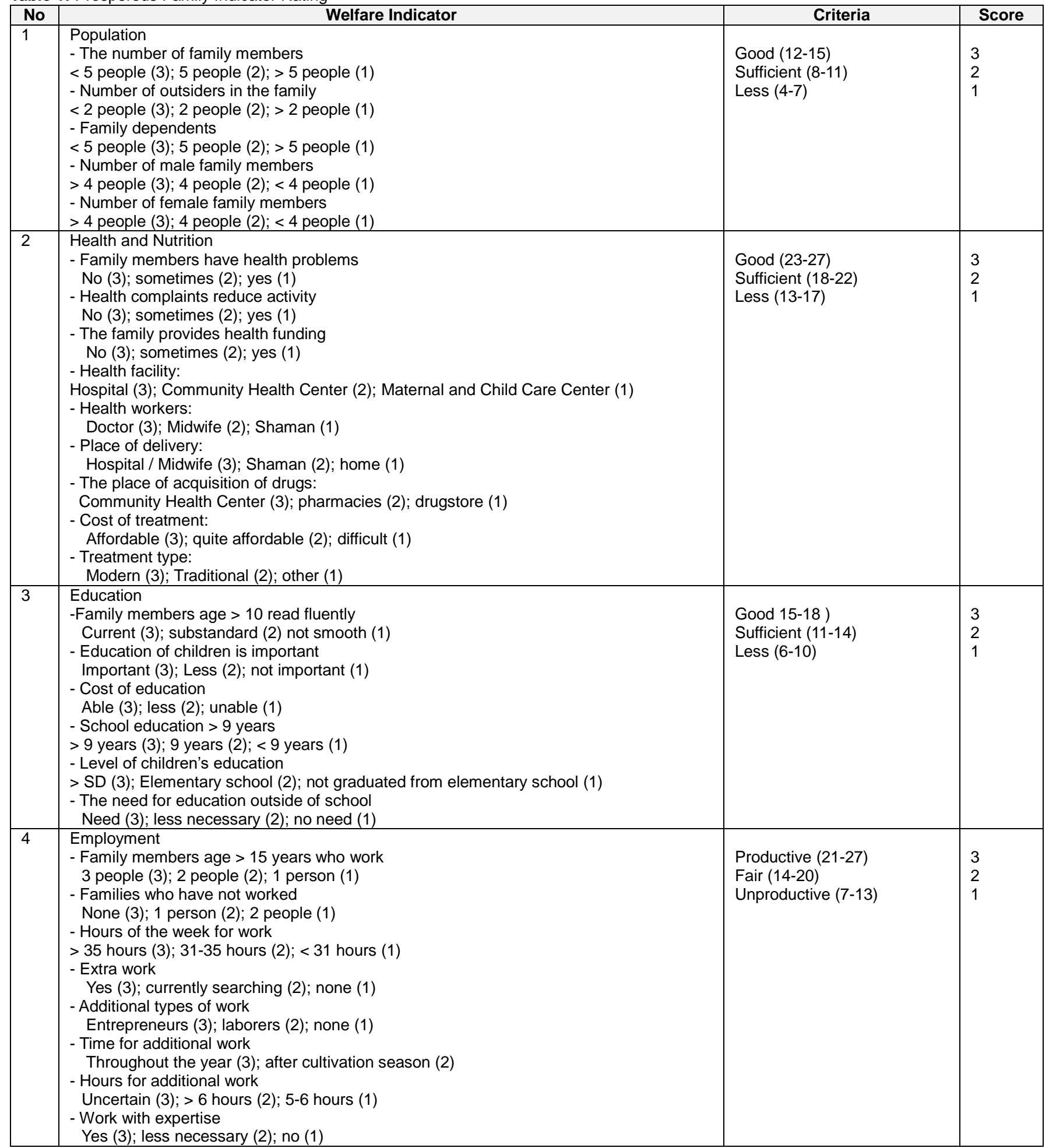




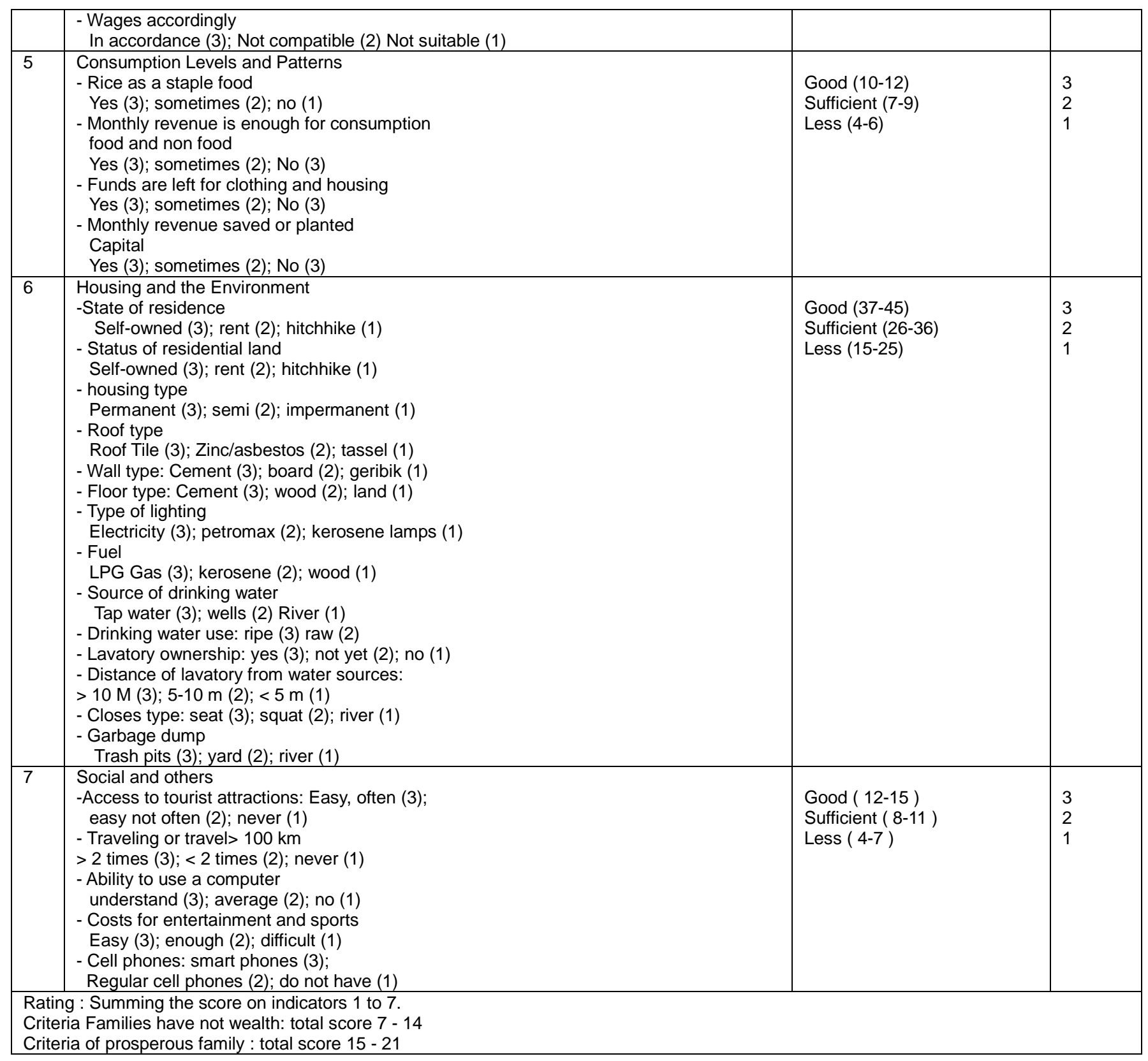

\subsection{Behavior of Household Production of Business Empowerment Participants}

\subsubsection{Productive Activity of Salt Ponds}

Salt production activities are carried out in the dry season started from July to November. Prior to pugar, the process of making salt was carried out on salt table without using a mat (geomembrane) so that the salt yield was dirty. The highest yield of salt production in the $\mathrm{K} 3$ category is salt with the lowest quality, has a $\mathrm{NaCl}$ content of less than 94.7 percent and a moisture content of more than 5 percent. The low quality of the salt produced, causes the selling price of salt. Pugar introduces the manufacture process of salt by using the method of Technology of Thread of Screw Filter
(TUF) and the use of Geoisolator. The TUF method uses the addition of threads at each stage of the selection, in order to circulate sea water in plots one to ten plots in turn. The purpose of adding threads is to accelerate seawater evaporation. Thus, the process of sea water getting older becomes faster and entering the salt table has reached 20 .

The presence of a filter screw in the salt production process will accelerate the length of salt making from 40 days of land preparation to 20 days. The use of geomembrane aims to improve the quality and quantity of salt production. The salt becomes cleaner. The use of the Geoisolator method can improve the quality of salt from the $\mathrm{K} 3$ category to the K2 and K1 categories. Type Salt K1 is a salt that has a concentration of at least $\mathrm{NaCl} 97.1 \%$, a maximum water content of $4 \%$ and the form of white 
crystals. While salt with $\mathrm{K} 2$ category is salt which has $\mathrm{NaCl}$ content and water content which is the same as Category K1 but physically colored rather brown, therefore it does not meet the standards for industrial raw materials. The impact of the improvement of production techniques with methods of TUF is production increase and quality of salt more. The average increase in salt production reaches $25 \%$ to $75 \%$ per production cycle. This is in accordance with the findings of Marefanda (2017) the implementation of the PUGAR program in Kebomas Gresik District could improve Kugar production from 40 tons/ha to 60 tons/ ha. Whereas, Pugar in Losarang of Indramayu met the salt production target of 90.34 tons/ha (Widiarto et al., 2013).

From the results of the study, salt production of Kugar participants in Pasuruan with average 80 tons per ha. The highest salt production is $380,000 \mathrm{~kg}$ with an area of 5 ha and the lowest production is $87,000 \mathrm{~kg}$ with an area of 1.2 ha. Marketing of salt production is still limited to salt collectors. Therefore, the price determination is still determined by the collectors. This limited marketing makes salt prices unstable. This is also linear with the findings of Prastio (2019); Marefanda (2017); Setyaningrum et al. (2015) the issue of marketing of community salt is very crucial, because salt farmers do not yet have a bargaining value in the sale of salt production. Both Prastio (2019) and Marefanda (2017) suggested that the government make strict rules on salt trading, making protection against salt prices in the form of setting the highest retail price. Setyaningrum et al. (2015) added that from the socio-cultural aspects and the sustainability of the salt pond business is quite high that will support the success of Pugar.

\subsubsection{Non-salt Pond Production Activities}

Salt ponds can only be carried out during the dry season. During the rainy season, salt farmers divert salt business to the cultivation of milkfish enlargement. About 25 salt farmers utilize the salt pond land to become a milkfish pond business. In a year, milkfish farming can be run for 2-3 production cycles. The effort to grow milkfish using milk seeds in $\log$ sizes of about $5 \mathrm{~cm}$ to $8 \mathrm{~cm}$. Thus, the maintenance period for milkfish can be shorter, between 2 to 3 months already harvested. Density of seed stocked an average of 1000 to 1500 per hectare. The maintenance of milkfish is done traditionally, relying on natural food. The size of milkfish harvested is an average size of 5 fishes per $\mathrm{kg}$. Yield milkfish farmer salt an average of 200-250 kg per harvest.

Some respondents of salt farmers have jobs not as milkfish farmers, but in other sectors outside the fishpond business. There is one (1) person who becomes a government office staff, three (3) respondents become teachers and two (2) respondents become traders. The work of traders is carried out when salt ponds cannot be done because of the rainy season.

\subsection{The Revenue of Participant}

The revenue of participants come from salt ponds, fish farming and other revenue both from the head of the household and the wife of his. The average salt yield of salt ponds is $124,000 \mathrm{~kg} /$ season per hectare. The average selling price of IDR. 1,100 per kilogram. This price is taken as medium price (K2), not quality 1 (K1) or low quality (K3). Therefore, the revenue from salt ponds per hectare is IDR. 136,400,000 per season. The advantage of a salt pond business is the difference between the revenue and the total costs incurred in the salt pond business. The amount of profit from salt ponds on average per hectare is IDR $65,100,000$ per season.

The yield of milkfish every enlargement period is $250 \mathrm{~kg}$ on average. Selling price per $\mathrm{kg}$ of IDR 16,000.00, than the revenue from the sale of milkfish is IDR 3,200.00, - each enlargement cycle. In one season, there are three maintenance cycles of milkfish. The total revenue of milkfish enlargement in one maintenance season is IDR. $12,000,000$. The benefit of milkfish enlargement business is obtained by reducing revenue with the total costs incurred in business activities in one season of maintenance. The total profit in the maintenance of milkfish in one maintenance season is IDR $4,750,000,-$. Some respondents have side jobs as traders. There are two respondents become traders with revenue of IDR 10.500.000, - .

The salt farmer's wife mostly contributes revenue to the salt farmer's household revenue. For about 19 respondents have wives who work as salt farmers, teachers, traders, open food stalls and private. The range of salt farmer's wife's revenue is between IDR. $15,000,000$ per year up to IDR $38,000,000$ per year.

\subsection{Household Expenditures of Participants}

The household expenditure consists of spending staple food and basic non-food. This kind of expenditure staple food household salt farmers are rice, corn, root - crops, side dishes (fish, meat, eggs), vegetables, fruits, sugar, coffee, cooking oil and so forth. Types of food that have been consumed in accordance with the criteria of healthy food. Average expenditure staple food of household salt farmers on average IDR 2.793,000 per month. Based on the number of family members, the highest percentage of salt farmers households has four family members as many as 19 households (59.38\%) followed by 5 family members approximately 7 households $(21.87 \%)$, then respondents who have 3 family members are 4 households $(12,5 \%)$ and the smallest household has 1 family member of 2 households $(6.25 \%)$. The average rice expenditure of $65 \mathrm{~kg}$ per month is reasonable because most respondents have family members of 4 to 5 people. In more detail it is presented in the Table 2 . 
Table 2: The Average of Household Food Expenditure Per Month

\begin{tabular}{|l|l|r|}
\hline Food Types & Total (Unit) & Total (IDR) \\
\hline Rise & $65 \mathrm{~kg}$ & IDR 715.000 \\
\hline Corn & $4 \mathrm{~kg}$ & IDR 28.000 \\
\hline Tubers & $3 \mathrm{~kg}$ & IDR 15.000 \\
\hline Fish & $5 \mathrm{~kg}$ & IDR 100.000 \\
\hline Chicken meat & $2 \mathrm{~kg}$ & IDR 70.000 \\
\hline Beef & $2 \mathrm{~kg}$ & IDR 220.000 \\
\hline Egg & $2 \mathrm{~kg}$ & IDR 50.000 \\
\hline Tempe & 15 pieces & IDR 45.000 \\
\hline Tofu & 10 pieces & IDR 20.000 \\
\hline Vegetables & 1 unit & IDR 110.000 \\
\hline Fruits & $6 \mathrm{~kg}$ & IDR 200.000 \\
\hline Herbs & 1 unit & IDR 100.000 \\
\hline Tobacco & 46 boxes & IDR 920.000 \\
\hline Milk & 5 carton & IDR 200.000 \\
\hline Total & IDR 2.793.000 &
\end{tabular}

Non-food staple household expenditure salt farmers consists of the electricity bill, the pulse, the cost of education, transport, health, installment loans, gathering, and clothing. Based on the type of non-food basic expenditure, it shows that the household farmers have paid attention to health, children's education and transportation for children's education. Non-food consumption in households of farmers in Pasuruan high on education costs. The Majority of household farmers' children in Pasuruan are students. The improvement of non-food staples is installment payments. Behaviors consumptive found in almost all households salt farmers. Most respondents spend revenue to buy secondary consumption on credit, giving rise to large installment payments. They would sell back items that have been purchased to be used as a capital initial salt ponds activity (see Table 3 .)

Table 3: Average Non-Food Expenditure Expenditures For Household Farmers

\begin{tabular}{|l|c|r|}
\hline Non-Food Type & Total (Unit) & \multicolumn{2}{|l|}{ Total (IDR) } \\
\hline Clothes & 5 unit & 350.000 \\
\hline Electricity Bills & 900 watt & 300.000 \\
\hline Taxes Bills & $200 \mathrm{~m}^{2}$ & 6.000 .000 \\
\hline Education Expenses & 3 Kids & 200.000 \\
\hline Health Expense & Monthly & 150.000 \\
\hline $\begin{array}{l}\text { Expense of } \\
\begin{array}{l}\text { Transportation } \\
\text { Equipment }\end{array}\end{array}$ & 15 liter \\
\hline Fuel Expense & 6 liter & 36.000 \\
\hline Credit Payment & Monthly & 1.500 .000 \\
\hline $\begin{array}{l}\text { Routine Social } \\
\text { Gathering }\end{array}$ & Monthly & 200.000 \\
\hline Credit & 30 thousand \\
and 5 GB & 100.000 \\
\hline Total & & $\mathbf{8 . 9 1 6 . 0 0 0}$ \\
\hline
\end{tabular}

The difference between household revenue and expenditure is obtained by household surplus. Based on all respondents, about 5 production house or as much as 15.6 percent of farm households have a deficit. Meanwhile, 27 production house or 84.4 percent of household farmers have a surplus. The reduction in household expenses can be met by other family members such as the salt farmer's wife and children.

\subsection{Family Welfare Level of Pugar Participants}

The level of welfare of salt farmers is measured by population, health and nutrition, education, employment, consumption level and patterns, housing and environment, and other social issues. First, Based on population indicators, all respondents are in the range of $8-11$, meaning that the welfare indicators of all salt household based on population have sufficient criteria with a score of 2 (see Table 4).

Table 4: Identification of Farmer Households Based on Population Criteria

\begin{tabular}{|l|c|c|c|}
\hline \multirow{2}{*}{ Indicators of Population } & \multicolumn{3}{|c|}{ Percentage } \\
\cline { 2 - 4 } & $\mathbf{3}$ & $\mathbf{2}$ & $\mathbf{1}$ \\
\hline $\begin{array}{l}\text { The number of family } \\
\text { member who join living }\end{array}$ & $16(50 \%)$ & $\begin{array}{c}15 \\
(47 \%)\end{array}$ & $\begin{array}{c}1 \\
(3 \%)\end{array}$ \\
\hline $\begin{array}{l}\text { The number of outsiders } \\
\text { join living }\end{array}$ & $30(94 \%)$ & $\begin{array}{c}2 \\
(6 \%)\end{array}$ & - \\
\hline Dependents in the family & $16(50 \%)$ & $\begin{array}{c}15 \\
(47 \%)\end{array}$ & $\begin{array}{c}1 \\
(3 \%)\end{array}$ \\
\hline $\begin{array}{l}\text { The number of male family } \\
\text { members }\end{array}$ & - & - & $\begin{array}{c}32 \\
(100 \%)\end{array}$ \\
\hline $\begin{array}{l}\text { The number of female } \\
\text { family members }\end{array}$ & - & - & $\begin{array}{c}32 \\
(100 \%)\end{array}$ \\
\hline
\end{tabular}

In addition, Table 5 provides information about the household health and nutrition. From the table it indicated that they have a value range of $23-27$ as many as 12 households with good criteria. While households that have a range of values $18-20$ as many as 20 households with sufficient criteria.

Table 5: Household Identification Based on Health and Nutrition
\begin{tabular}{|l|c|c|c|}
\hline $\begin{array}{l}\text { Indicators of Health } \\
\text { and Nutrients }\end{array}$ & \multicolumn{3}{|c|}{ Score (Percentage) } \\
\cline { 2 - 4 } & $\mathbf{3}$ & $\mathbf{2}$ & $\mathbf{1}$ \\
\hline $\begin{array}{l}\text { Family members } \\
\text { complain about health }\end{array}$ & $\begin{array}{c}15 \\
(47 \%)\end{array}$ & $\begin{array}{c}14 \\
(44 \%)\end{array}$ & $\begin{array}{c}3 \\
(9 \%)\end{array}$ \\
\hline $\begin{array}{l}\text { Health complaints } \\
\text { decrease daily } \\
\text { activities }\end{array}$ & $\begin{array}{c}22 \\
(69 \%)\end{array}$ & $\begin{array}{c}10 \\
(31 \%)\end{array}$ & - \\
\hline $\begin{array}{l}\text { Each month the family } \\
\text { provides health fund }\end{array}$ & $\begin{array}{c}6 \\
(19 \%)\end{array}$ & $\begin{array}{c}16 \\
(50 \%)\end{array}$ & $\begin{array}{c}10 \\
(31 \%)\end{array}$ \\
\hline Health Facilities & $\begin{array}{c}3 \\
(9 \%)\end{array}$ & $\begin{array}{c}29 \\
(91 \%)\end{array}$ & - \\
\hline Health labors & $\begin{array}{c}23 \\
(72 \%)\end{array}$ & $\begin{array}{c}9 \\
(28 \%)\end{array}$ & - \\
\hline Place of labor & $\begin{array}{c}32 \\
(100 \%)\end{array}$ & - & - \\
\hline Pharmacy & $\begin{array}{c}14 \\
(44 \%)\end{array}$ & $\begin{array}{c}16 \\
(50 \%)\end{array}$ & $\begin{array}{c}2 \\
(6 \%)\end{array}$ \\
\hline Cost of treatment & - & $\begin{array}{c}32 \\
(100 \%)\end{array}$ & - \\
\hline Type of Treatment & $\begin{array}{c}32 \\
(100 \%)\end{array}$ & - & - \\
\hline
\end{tabular}

Furthermore, Table 6 presents the results of identifying the level of household welfare of salt farmers based on educational indicators. From the table, it can be seen that all households are fluent in reading and writing, perceptions about education are all important, households are able to pay for school children, all children are more than 9 years old and have more than junior high school education. As for education outside of school, several households stated that it 
was necessary; less necessary and unnecessary. Based on the value of the indicators of household education ranged from 16 to 18 , this shows that the value of education for all respondents on good criteria.

Identification of employment to measure the level of welfare of saltwater households is presented in Table 7. The results of the labor tabulation showed that all households have more than 35 hours of work a week, all households have additional work because the salt commodity is seasonal and the type of additional work is self-employed. The total score of the farmer's household employment indicator is in the range of 23 to 26. It implies that the salt farm household in the study area is productive.

Table 6: Household Identification Based on Education

\begin{tabular}{|c|c|c|c|}
\hline \multirow{2}{*}{$\begin{array}{l}\text { Indicators of } \\
\text { Education }\end{array}$} & \multicolumn{3}{|c|}{ Score (Percentage) } \\
\hline & 3 & 2 & 1 \\
\hline $\begin{array}{l}\text { Family Member Age } \\
>10 \text { years old can } \\
\text { read and write fluently }\end{array}$ & $\begin{array}{c}32 \\
(100 \%)\end{array}$ & - & - \\
\hline $\begin{array}{l}\text { Perception of } \\
\text { Education for } \\
\text { Children (male and } \\
\text { female) }\end{array}$ & $\begin{array}{c}32 \\
(100 \%)\end{array}$ & - & - \\
\hline $\begin{array}{l}\text { The Capability of } \\
\text { Funding The } \\
\text { Education }\end{array}$ & $\begin{array}{c}32 \\
(100 \%)\end{array}$ & - & - \\
\hline $\begin{array}{l}\text { The Duration of } \\
\text { Education at School }\end{array}$ & $\begin{array}{c}32 \\
(100 \%)\end{array}$ & - & - \\
\hline Kids Education Level & $\begin{array}{c}32 \\
(100 \%)\end{array}$ & - & - \\
\hline $\begin{array}{l}\text { Perception of Non } \\
\text { Formal Education }\end{array}$ & $\begin{array}{c}12 \\
(38 \%)\end{array}$ & $\begin{array}{c}10 \\
(31 \%)\end{array}$ & $\begin{array}{c}10 \\
(31 \%)\end{array}$ \\
\hline
\end{tabular}

Table 7: Household Identification Based on Employment

\begin{tabular}{|l|c|c|c|}
\hline $\begin{array}{l}\text { Indicators of } \\
\text { Employment }\end{array}$ & \multicolumn{3}{|c|}{ Score (Percentage) } \\
\cline { 2 - 4 } $\begin{array}{l}\text { Family members age } \\
> \\
15 \text { years old and } \\
\text { working at the } \\
\text { moment }\end{array}$ & $\begin{array}{c}6 \\
(19 \%)\end{array}$ & $\begin{array}{c}17 \\
(53 \%)\end{array}$ & $\begin{array}{c}9 \\
(28 \%)\end{array}$ \\
\hline $\begin{array}{l}\text { Family members who } \\
\text { still do not work }\end{array}$ & $\begin{array}{c}22 \\
(69 \%)\end{array}$ & $\begin{array}{c}10 \\
(31 \%)\end{array}$ & - \\
\hline $\begin{array}{l}\text { Total hours of work in } \\
\text { a week }\end{array}$ & $\begin{array}{c}32 \\
(100 \%)\end{array}$ & - & - \\
\hline Additional job & $\begin{array}{c}32 \\
(100 \%)\end{array}$ & - & - \\
\hline Type of additional job & $\begin{array}{c}32 \\
(100 \%)\end{array}$ & - & - \\
\hline Time for additional job & $\begin{array}{c}5 \\
(16 \%)\end{array}$ & $\begin{array}{c}27 \\
(84 \%)\end{array}$ & - \\
\hline $\begin{array}{l}27 \\
\text { jours for additional }\end{array}$ & $\begin{array}{c}5 \\
(84 \%)\end{array}$ & $\begin{array}{c}32 \\
(16 \%)\end{array}$ & - \\
\hline Work with expertise & $\begin{array}{c}32 \\
(100 \%)\end{array}$ & - & - \\
\hline Suitable salary & $\begin{array}{c}32 \\
(100 \%)\end{array}$ & - & \\
\hline
\end{tabular}

In accordance with the level and household consumption, it indicate that all respondents used rice as a staple food. Some respondents found that revenue was not enough for basic food and non-food needs (16\%), but the majority (75\%) of respondents stated that excess revenue was to meet food and non-food needs. Insufficient revenue because households have a lot of installments for the purchase of consumer goods. However, there are some respondents leaving their revenue to save or to increase capital. Based on indicators of consumption levels and patterns, about 8 households in the range of values 7-9 with sufficient criteria. In the other hand, 24 households in the range of 10-12 scores with good criteria (see Table 8).

Table 8: Household Identification Based on Consumption Level and Pattern

\begin{tabular}{|c|c|c|c|}
\hline \multirow{2}{*}{$\begin{array}{l}\text { Indicators of } \\
\text { consumption } \\
\text { pattern and level }\end{array}$} & \multicolumn{3}{|c|}{ Score (Percentage) } \\
\hline & 3 & 2 & 1 \\
\hline Rice as the main food & $\begin{array}{c}32 \\
(100 \%)\end{array}$ & - & - \\
\hline $\begin{array}{l}\text { Sufficient monthly } \\
\text { income for food } \\
\text { consumption and non } \\
\text { food consumption }\end{array}$ & $\begin{array}{c}24 \\
(75 \%)\end{array}$ & $\begin{array}{c}3 \\
(9 \%)\end{array}$ & $\begin{array}{c}5 \\
(16 \%)\end{array}$ \\
\hline $\begin{array}{l}\text { Remained fund for } \\
\text { the needs of clothes } \\
\text { and house }\end{array}$ & $\begin{array}{c}24 \\
(75 \%)\end{array}$ & $\begin{array}{c}8 \\
(25 \%)\end{array}$ & - \\
\hline $\begin{array}{l}\text { Monthly income is } \\
\text { saved or for additional } \\
\text { capital }\end{array}$ & $\begin{array}{c}10 \\
(31 \%)\end{array}$ & $\begin{array}{c}13 \\
(41 \%)\end{array}$ & $\begin{array}{c}9 \\
(28 \%)\end{array}$ \\
\hline
\end{tabular}

The results of the tabulation of housing and the environment is provided in the Table 9. It shows that all respondents have the status of residence of their own home and the status of their own land. All respondents also have houses with tiled roofs, with cement or ceramic floors and permanent housing types. All respondents have used electricity as lighting, and fuel uses LPG for cooking. Some households each use wells to get clean water. Based on these scores, all salt farmer households are in good criteria.

Table 9: Household Identification Based on Housing and Environment

\begin{tabular}{|l|c|c|c|}
\hline \multirow{2}{*}{$\begin{array}{l}\text { Indicators of House and } \\
\text { Environment }\end{array}$} & \multicolumn{3}{|c|}{ Score (Percentage) } \\
\cline { 2 - 4 } & $\mathbf{3}$ & $\mathbf{2}$ & $\mathbf{1}$ \\
\hline Status of residence & $32(100 \%)$ & - & - \\
\hline Status of residence land & $32(100 \%)$ & - & - \\
\hline Type of residence & $32(100 \%)$ & - & - \\
\hline Type of roof & $32(100 \%)$ & - & - \\
\hline Type of wall & $32(100 \%)$ & - & - \\
\hline Type of floor & $32(100 \%)$ & - & - \\
\hline $\begin{array}{l}\text { The large of floor is enough } \\
\text { for each family members }\end{array}$ & $32(100 \%)$ & - & - \\
\hline Type of lighting & $32(100 \%)$ & - & - \\
\hline Fuel & $32(100 \%)$ & - & - \\
\hline Source of water & $15(47 \%)$ & $17(53 \%)$ & - \\
\hline The usage of water & $32(100 \%)$ & - & - \\
\hline Toilet ownership & $32(100 \%)$ & - & - \\
\hline Distance of toilet & $27(84 \%)$ & $5(16 \%)$ & - \\
\hline Type of toilet & $32(100 \%)$ & - & - \\
\hline Landfills & $32(100 \%)$ & - & - \\
\hline
\end{tabular}

Lastly, social welfare criteria and others are measured based on indicators of household access to tourist attractions showing that households are easy and frequent to tourist attractions, as well as easy but not often to tourist attractions. The results of the study is illustrated in the Table 10. From the table it can be known that the entire household is less 
than two times traveled with a distance of more than $100 \mathrm{~km}$. Based on the indicator of the ability to use a computer, household members understand using a computer, but also found several households that do not understand. Based on entertainment and sports cost indicators, all households choose enough. While the use of cellular phone is mostly already using smartphones. A total of 22 households have a total score of 8-11 indicating the criteria of social welfare and others are in sufficient condition. A total of 10 households have a total score of 12-15 showing good conditions.

Table 10: Household Identification Based on Social and Others

\begin{tabular}{|l|c|c|c|}
\hline Indicators of & \multicolumn{3}{|c|}{ Score (Percentage) } \\
\cline { 2 - 4 } social and others & $\mathbf{3}$ & $\mathbf{2}$ & $\mathbf{1}$ \\
\hline $\begin{array}{l}\text { Access to tourism } \\
\text { places }\end{array}$ & $16(50 \%)$ & $16(50 \%)$ & - \\
\hline $\begin{array}{l}\text { Travelling with } \\
\text { distance more } \\
\text { than 100 km }\end{array}$ & - & $32(100 \%)$ & - \\
\hline $\begin{array}{l}\text { The ability of } \\
\text { using computer }\end{array}$ & $-22(69 \%)$ & $10(31 \%)$ \\
\hline $\begin{array}{l}\text { Expense for } \\
\text { entertainment and } \\
\text { sport }\end{array}$ & - & $32(100 \%)$ & - \\
\hline $\begin{array}{l}\text { The ownership of } \\
\text { cellular phone }\end{array}$ & $22(69 \%)$ & $10(31 \%)$ & - \\
\hline
\end{tabular}

\section{Conclusion}

The study is intended to analysis the relationship between business program and household welfare level of farmers which measured by several indicators such as the number of family member, health and nutrition, education, income, consumption level, housing, and social activities. From the findings it can be concluded that household revenue sources for some salt farmers also come from nonsalt pond business activities. Farmer household revenue can be used to meet staple food consumption and non-food staple consumption. Based on the indicators of family welfare, households participating in the empowerment program were group into the category of prosperous families. In order to stabilize the price of salt at the producer level, government intervention in the people's salt trading system is needed.

\section{References}

Acharya, S., Yoshino, E., Jimba, M., \& Wakai, S. (2005). Empowering rural women through a community development approach in Nepal. Community Development Journal, 42(1), 34-46.

DOI: $10.1093 / \mathrm{cdj} / \mathrm{bsi064}$

Biswas, W. K., Bryce, P., \& Diesendorf, M. (2001). Model for empowering rural poor through renewable energy technologies in Bangladesh. Environmental Science \& Policy, 4(6), 333-344.

DOI: $10.1016 / \mathrm{S} 1462-9011(01) 00031-4$

Chambers, R. (1996). PRA participatory rural appraisal Memahami Desa Secara Partisipatif. Yogyakarta, Indonesia: Penerbit Kanisius.

Constantino, P., Carlos, H., Ramalho, E., Rostant, L., Marinelli, C. E., Teles, D., Fonseca Jr., S., Fernandes, R., \& Valsecchi, J. (2012). Empowering local people through community-based resource monitoring: A comparison of Brazil and Namibia. Ecology and Society, 17(4), 22. https://doi.org/10.5751/ES-05164-170422

Garikipati, S. (2008). The impact of lending to women on household vulnerability and women's empowerment: Evidence from India. World Development, 36(12), 26202642.

Jagger, P. (2008). Forest incomes after Uganda's forest sector reform: Are the rural poor gaining? CAPRi working paper No. 92. International Food Policy Research Institute, Washington, D.C., USA. Retrieved September 30, 2019 from http://ebrary.ifpri.org/utils/getfile/collection/p15738coll2 /id/22543/filename/22544.pdf

Khan, R. E. A., Rehman, H., \& Haq, M. A. (2015). Determinants of rural household poverty: The role of household socioeconomic empowerment. AmericanEurasian Journal of Agriculture \& Environmental Science, 15(1), 93-98. https://doi.org/10.5829/idosi.aejaes.2015.15.1.1050

Marefanda, N. (2018). Evaluasi Program Nasional Pemberdayaan Masyarakat Mandiri Kelautan dan Perikanan RI No. Per. 06/Men/2011 di Kabupaten Gresik. Jurnal Public Policy, 3(2), 36-49. https://doi.org/10.35308/jpp.v3i2.63

Prastio, L. O. (2019). Strategi Program Pemberdayaan Usaha Garam Rakyat di Desa Muara Baru Kecamatan Cilamaya Wetan Kabupaten Karawang. The Indonesian Journal of Politics and Policy, 1(1), 62-73.

Setyaningrum, R., Anomsari, A., Hartini, E., \& Suprijono, H. (2015). Tingkat Pemberdayaan Usaha Garam Rakyat (Pugar) Ditinjau dari Aspek Produksi, Distribusi, Permintaan Pasar dan Sosial Budaya. Jurnal Teknik Industri, 10(1), 55-62.

Sulistiyani, A. T. (2007). Konseptualisasi Model Pemberdayaan LSM sebagai Fasilitator Pembangunan. Jurnal Kebijakan dan Administrasi Publik, 11(2), 139157. https://doi.org/10.22146/jkap.8564

Trikobery, J., Rizal, A., Kurniawati, N., \& Anna, Z. (2017). Analisis Usaha Tambak Garam di Desa Pengarengan Kecamatan Pangenan Kabupaten Cirebon. Journal Perikanan Kelautan, 8(2), 168-175.

Weber, O., \& Ahmad, A. (2014). Empowerment through microfinance: The relation between loan cycle and level of empowerment. World Development, 62, 75-87. https://doi.org/10.1016/j.worlddev.2014.05.012 